\title{
The effect of collaborative writing strategy with google docs and motivation towards eighth grade students' writing ability on descriptive text
}

\author{
Reka Agustin ${ }^{1}$, Rusman Roni ${ }^{2}$ \\ ${ }^{1}$ Sekolah Menengah Pertama Negeri 12 Palembang, Indonesia \\ ${ }^{2}$ Universitas Tridinanti Palembang, Indonesia
}

\section{Article Info}

\section{Article history:}

Received Jul 16 $6^{\text {th }}, 2021$

Revised Aug $11^{\text {th }}, 2021$

Accepted Aug 30, 2021

\section{Keyword:}

Collaborative Writing Strategy with Google Docs, Conventional Method, Students' motivation, Writing Ability.

\begin{abstract}
This study was to investigate the effect of collaborative writing strategy with google docs and motivation towards eight grade students' writing abilty on descriptive text at SMPN 12 Palembang. The population of this study was all the eight grade students of SMPN 12 Palembang which total is 252 students. The sample was 64 students taken by using statified random sampling. In carrying out of the research, the writer used an experimental method : factorial design. The writer distributed pretest, posttest, and motivation questionnairein collecting data. Then in analyzing the data the writer used paired sample test, independent sample t-test and two way ANOVA. The result of this study analysis indicated that, first, there was a significant difference between writing ability of the eighth grade students with high motivation and those with low motivation taught through collaborative writing strategy with google docs. Second, there was a significant difference between writing ability of the eighth grade students with high motivation and low motivation taught through conventional method. Third, there was a significant difference between writing ability of the eighth grade students with high motivation and low motivation taught through collaborative writing strategy with google docs and those with high motivation and low motivation taught through conventional method. Fourth, there were significant interaction effect of collabotrative writing strategy with google docs and the eighth grade students' motivation towards writing ability.
\end{abstract}

(C) 2021 The Authors. Published by IICET

This is an open access article under the CC BY-NC-SA license (https://creativecommons.org/licenses/by-nc-sa/4.0

\section{Corresponding Author:}

Agustin, R.,

Sekolah Menengah Pertama Negeri 12 Palembang, Indonesia

Email: rekha.agustin12@gmail.com

\section{Introduction}

Writing is one of the important skills because it takes a part as an important comunications tools. through writing, everybody is not only to express feeling and ideas, but also to communicate with others and have remembering facts and ideas.

Understanding the necessary of writing, in the 2013 curriculum writing has become one of the language skills that students must have. By having writing skills, students can convey their thoughts, ideas, 
feelings, or experiences into written work so that they can be accepted by others. In modern society, people acquire a great deal of knowledge about the world through writing rather than through direct personal experience. Indeed writing is important in obtaining knowledge and preserving information.

Based on the information by the English teacher interview that many students received under the minimum standards of achievement in writing ability. It can be seen from the table 1 below.

Table 1. Student's Score in Writing Ability

\begin{tabular}{lccc}
\hline NO & Score & Frequency & Percentage \\
1 & $91-100$ & 2 & $6,25 \%$ \\
2 & $83-90$ & 4 & $12,5 \%$ \\
3 & $76-82$ & 8 & $25 \%$ \\
4 & $0-75$ & 18 & $56,25 \%$ \\
\end{tabular}

Based on the data above, the result of reading test at eighth grader showed that most of the students got lower scores under the passing grade. The passing grade is 75 . The scores of the students got from written test which was done by the teacher. KEMENDIKBUD (2017) stated that a written test is a test used for measuring cognitive skills. The writer found students' witing assessment in the preliminary study who got score than 91 only 2 students. Those students more than 83 were only 4 students. Those who got between 76 and 82 were 8 students, and the other students got less than 75 from totally 32 students in that class. It means many students got under the minimum passing grade (KKM:Kriteria Ketuntasan Minimal) in writing.

Based on the data above, it was also noticed that the eighth graders at SMP Negeri 12 palembang (State Junior High School) had difficulties to write a text. Where most students still faced difficulties dealing with writing text in English as their foreign language with regard to the preliminary observation.

Another important element to developing their writing skills is motivation, Learning motivation of students in writing is important. Without learning motivation is not possible. So in writing the role of motivation is effective on students learning. Due to motivation students do any task and achieve the goal. Motivation increase speed of work and aperson is doing everything to achieve goal. [1] Motivation increases the performance of learning. It provide energy and learner achieve the task because she has a direction and performance of learneris increase, in education of motivation effect on students success. Motivation is a factor of high or low of the goal.

Therefore, there must be appropriate techniques to develop students' writing skills. Collaborative writing, as a technique for improving students' writing skills, can be an alternative. "Several studies have shown that collaborative writing enhances and stimulates students' motivation to improve writing skills."

Considering the problems above, students should have an interesting learning process, especially for writing. One of the media that can be used by teachers in learning to write is Google Docs. Google doc is one of the features of Google that is presented to all its users which can be used as a medium for writing collaboration where all students in one class can contribute to making good writing.

[2] An online application, is a promising tool for collaborative learning. This can facilitate collaborative writing and editing among students. With regard to the description above, the writer conduct a study entitled To improve students' writing skills especially in writing descriptive text paragraphs by the theme " describing place" the writer plans to conduct studying writing. This research proposal is entitled " The Effect of Collaborative Writing Strategy with Google docs and Motivation Towards Eight Grade Students' Writing Ability on Descriptive Text at SMPN 12 Palembang."

\section{The Objective of the Study}

The objectives of this study are to find out whether or not: 1) There was any significant difference in writing ability between the students who have high motivation and those who have low motivation taught by using collaborative writing strategy with google docs at SMPN 12 Palembang.2) There was any significant difference in writing ability between the students who have high motivation and those who have low motivation taught by using conventional writing strategy at SMPN 12 Palembang. 3) There was any significant difference in writing ability between the students who have high motivation and those who have low motivation taught by using collaborative writing startegy with google docs and conventional writing strategy at SMPN 12 Palembang. 4) There was any significant interaction effect of collaborative writing strategy with google docs and motivation towards eight grade students' writing ability on descriptive text at SMPN 12 Palembang. 


\section{Literature Review}

1. The Concept of Collaborative Strategy

Collaborative strategy is a recursive process in which two or more students work together, it is the intersection of command objectives with knowledge sharing and learning. Collaborative strategy which is also called "collaboration" is the process of working with others on writing or on other projects and is an important component of contextual teaching and learning.

Collaborative learning activities are mostly centered on the exploration or application of subject matter by students. Collaborative learning is a situation where two or more people learn or try to learn something together.

\section{Concept of Collaborative Writing}

The basis of the power of collaborative writing lies in collaborative learning. In practical terms, every writing activity moves the document from revision to next revision. In addition, there are also revisions that do not contain significant changes. Therefore, certain documents consist of many revisions over time. Collaborative writing can be understood as one type of collaborative learning among many, it really is far more than this. [3] Collaborative writing as involving more than one person who contributes to the creation of a text so that sharing responsibility becomes essentials.

The concept of teaching writing skill is shifting, and teachers are faced with adapting their teaching practice to integrate new technologies while redefining writing and learning for 21th century [4]. In a writing classroom, collaborative writing can also be encouraged with the use of the World Wide Web. With the development and advancement of computer networks, online collaborative learning becomes possible even if students cannot meet in a classroom. Many institutions have attempted to use of technology in collaborative activities.

Apart from blogs, wikis, chat rooms, forums, learning logs, Google documents are digital lawsuit online tools that give teachers or lecturers some advanced features to help 21st century students develop their writing skills.

Collaborative writing means students write text, are complemented by group members and share ideas and that will be corrected and supported by other members.By working collaboratively, students could enjoy in writing process. In collaborative writing, students can easily develop ideas and take comments or arguments from others.

3. Google Docs Tool for Collaborative Writing

Google Docs is a free online word processor available to anyone with a Gmail account to create collaborative activities. This tool provides standard editing functionality and is very superior in realtime collaborative writing. It allows users to create, edit and store their document online [5] An extensive revision history is maintained. It is possible to view all documents as they appear at any time by viewing the revision history feature in Google Docs. An author can choose to return to the previous version. This tool allows many groups or small pairs to open one Google word document through a link and edit the document simultaneously. The teacher can provide immediate feedback by leaving comments and editing where and when needed. Any feedback given by the lecturer remains part of the document and is thus available for students to review later. Students can also see the work of other groups, as well as the feedback given to them, then learn from it.

Here, is a favorite of the Google docs feature, all of which are greatly appreciated by the author: many authors can edit documents simultaneously, each author's changes appear immediately next to the individual colored cursors, even editing is quite complicated, such as cut and paste done miraculously. , you can select the text area with comments, maybe explain the decision behind the edits, or ask other writers' work.

These comments can be threaded, and deleted after being marked as resolved. All comments are saved for posterity in a separate "discussion" document, which can always refer back to, chat to the window is also available which is useful for resolving problems in real-time, the full revision history is maintained and can be returned to the previous version very easily. 
Because Google docs are easy and fast, this tool is perfect for facilitating digital writing workshops that combine peer editing with cooperative grouping and fine-tuned small group writing instructions. This special feature makes Google docs a powerful program that can facilitate collaborative writing in the language classroom. [6] Google Docs is a productive tool where learning activity can be designed differently and creatively. For example, an instructor might post a text, which is intentionally full of mistakes, to be corrected by students. Likewise, students can easily edit peers, because the program leaves an editing trail. Another option is the story chain, where an instructor starts a story that contributes to each student in turn. In addition, this tool is useful in general group projects.

\section{Concept of Motivation}

There are various definitions of motivation from many experts, [7] Motivation is kind of internal drive that encourage somebody to pursue a course of action. Students are highly motivated to do whatever is necessary to achieve their goals. A motivated language learner may understand goals of various kinds. Motivation is characterized as the process where goal-oriented action is initiated, directed and sustained. Motivation, whether it's having a glass of water to alleviate thirst or reading a book to acquire information, is what drives us to act. [1] motivation is the highest when one can make one's own choices, whether they be in short-term or long-term contexts.

Motivation had an important role in the language learning process. Motivation was like a selfregulator that generates a desire to learned. Students who were motivated were more successful than students who were not motivated. However, some students who were not motivated were basically able to practiced their writing skills. Motivated students need to forced themselves to practiced and get used to writing in english. Motivation encourages students to pay more attention to the subject matter. Motivation makes students ready for the teaching and learning process. So that students more easily understand the material in learning to write. Motivated students could practiced their abilities in their spare time.

This was because there was a feeling of enjoying themselves so that they were happy in doing this activity, students who were motivated succeed in writing skills. Because they pay attention to material. Students also pay attention to how the teacher writes words. When the teacher gives examples of words, they pay attention to the written word. When they encountered difficulties, they asked the teacher to repeated the words.

\section{Method}

\section{Types of research}

This quantitative study employed experimental method. The factorial design is used. The writer divides the students into two classes. They are (1) the experimental class; the class that uses collaborative writing strategy with google docs and (2) the control class. The writer gives pretest and posttest, and students' motivation questionnaire. Furthermore, students' motivation is grouped the students into two categories; high and low students' motivation.

\begin{tabular}{llllll}
\multicolumn{7}{l}{ Table 2<Factorial Design $>$} \\
\hline Experimental Group & $\mathrm{R}$ & $\mathrm{O}_{1}$ & $\mathrm{X}$ & $\mathrm{Y}_{1}$ & $\mathrm{O}_{2}$ \\
Control Group & $\mathrm{R}$ & $\mathrm{O}_{3}$ & $\mathrm{C}$ & $\mathrm{Y}_{1}$ & $\mathrm{O}_{4}$ \\
Experimental Group & $\mathrm{R}$ & $\mathrm{O}_{5}$ & $\mathrm{X}$ & $\mathrm{Y}_{2}$ & $\mathrm{O}_{6}$ \\
Control Group & $\mathrm{R}$ & $\mathrm{O}_{7}$ & $\mathrm{C}$ & $\mathrm{Y}_{2}$ & $\mathrm{O}_{8}$ \\
\hline Source: Fraenkel et $(2012 \cdot 277)$ & & & &
\end{tabular}

Source: Fraenkel et al (2012:277)

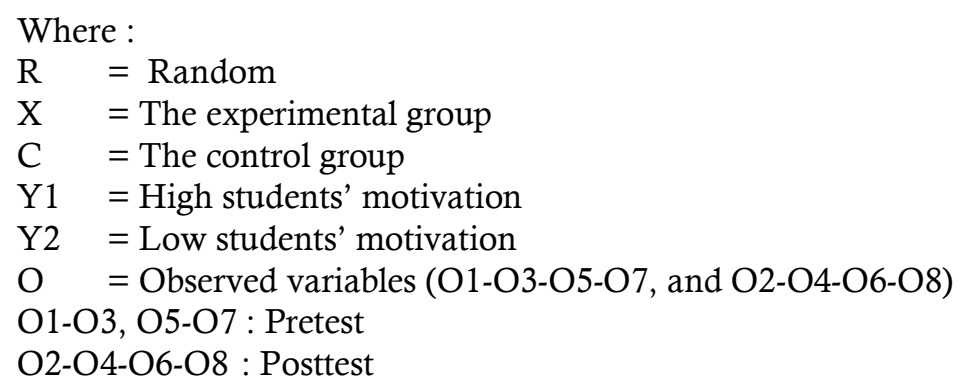


$\mathrm{O} 1$ and $\mathrm{O} 3$ : Pretest for experimental group and conventional teaching method (control group ) before treatment for high students' motivation (Y1)

$\mathrm{O} 2$ and $\mathrm{O} 4$ : Posttest for experimental group and conventional teaching method (control group) after treatment for high students' motivation (Y1)

O5 and $\mathrm{O} 7$ : Pretest for experimental group and conventional teaching method (control group ) before treatment for low students' motivation (Y2) 06 and 08 : Posttest for experimental group and conventional teaching method (control group) after treatment for low students' motivation (Y2)

In this factorial design, the experimental class was consisted of the students who has high motivation and those who has low motivation taught by using collaborative writing strategy with google docs to influence the students' writing abilty and then the control class was consisted of the students who has high motivation and those who has low motivation taught by using conventional teaching technique (no treatment) in teaching writing descriptive text.

\section{Research Subjects and Data}

The subjects in this study comprised eighth-grade students at SMPN 12 Palembang. Sampling was done using a stratified random sampling technique, in which the sample was categorized into high, and low motivation consisting of 64 students. The research data were obtained utilizing a questionnaire to determine students' writing motivation and writing test to deterrmine students' writing ability. The instrument used had been validated through content validity. To check validity of the test, the writer used correlation product moment (person's correlation) with an assist of SPSS 25. To know whether the test items were valid or not.

Realibility writing test is measured by using inter-rater reliability in which two or more raters score the answer of the same student and the scores are then correlated. Reability writing test were analyzed using Spearman rank correlation. The instrument's reliability in this study was obtained from Cronbach's alpha testing on motivation.

Analysis of the value of the pretest, posttest, and student questionnaires in the experimental and control classes were analyzed through descriptive analysis, and hypothesis testing consisting of the anova test and ttest.

\section{Results and Discussions}

\section{Prerequisite Analysis}

The writer used for statistical in analyze the data collected. They were follows: (1) the statistical analyses on measuring normality of the data, (2) the statistical on measuring homogeneity of the data.

\section{Normality test}

The normality test was used to find out whether or not the data of the pretest and posttest in experimental and control group gained were distributed normally. In analyzing the normality of the data, the writer used SPSS version 25. The distribution of the data can be classified into normal if the pvalue is higher than mean significant difference at 0.05 levels.

Table $3<$ Test of Normality>

\begin{tabular}{|c|c|c|c|c|c|c|}
\hline \multicolumn{7}{|c|}{ Tests of Normality } \\
\hline & Statistic & df & Sig. & Statistic & $\mathrm{df}$ & Sig. \\
\hline Pretest in experimental group & ,201 & 16 &, 084 & ,912 & 16 &, 125 \\
\hline $\begin{array}{l}\text { Posttest in experimental } \\
\text { group }\end{array}$ & 186 & 16 &, 140 & ,951 & 16 & ,505 \\
\hline Pretest in control Group & 170 & 16 & ,200* & ,955 & 16 &, 578 \\
\hline Posttest in Control Group &, 153 & 16 & $200^{*}$ & ,887 & 16 & 049 \\
\hline
\end{tabular}

*. This is a lower bound of the true significance.

a. Lilliefors Significance Correction

From the statistical calculation by using normality test of Kolmogorov-Smirnov test in table 3, it was found that the students pretest and posttest in experimental group were 0,84 and 0,140 . The students' pretest and posttest in control group were 0,200 and 0,200 . So, all data were categorized into normal distribution since the $\mathrm{p}$-value were higher than the significant at 0,05 level. Therefore, the data for research are in normal distribution 
2. Homogeneity Test

Levene Statistic was applied to analyze the students' posttest score in experimental and control group are homogeneous or not. The samples are considered homogenous whenever p-value is higher than mean significant difference at 0,05 . The calculation of the homogeneity test by using Levene Statistic is displayed in table 2 .

Test of Homogeneity of Variances

Table $4<$ Homogeneity Test $>$

\begin{tabular}{llllll} 
& & Levene Statistic & df1 & df2 & Sig. \\
Students' & Based on Mean & 3,667 & 1 & 30 &, 065 \\
Posttest & Based on Median & 2,924 & 1 & 30 &, 098 \\
Score & $\begin{array}{l}\text { Based on Median and with } \\
\text { adjusted df }\end{array}$ & 2,924 & 1 & 29,495 &, 098 \\
& Based on trimmed mean & 3,723 & 1 & 30 &, 063 \\
\hline
\end{tabular}

In line with calculation table 4 of Levene Statistic, it was found that $p$-value is 0,065 . This value is higher than 0,05 . Therefore the data for the research are homogeneous.

3. Hypothesis Testing

Table $5<$ Paired Sample T Test Hypothesis 1: Paired Samples Test $>$

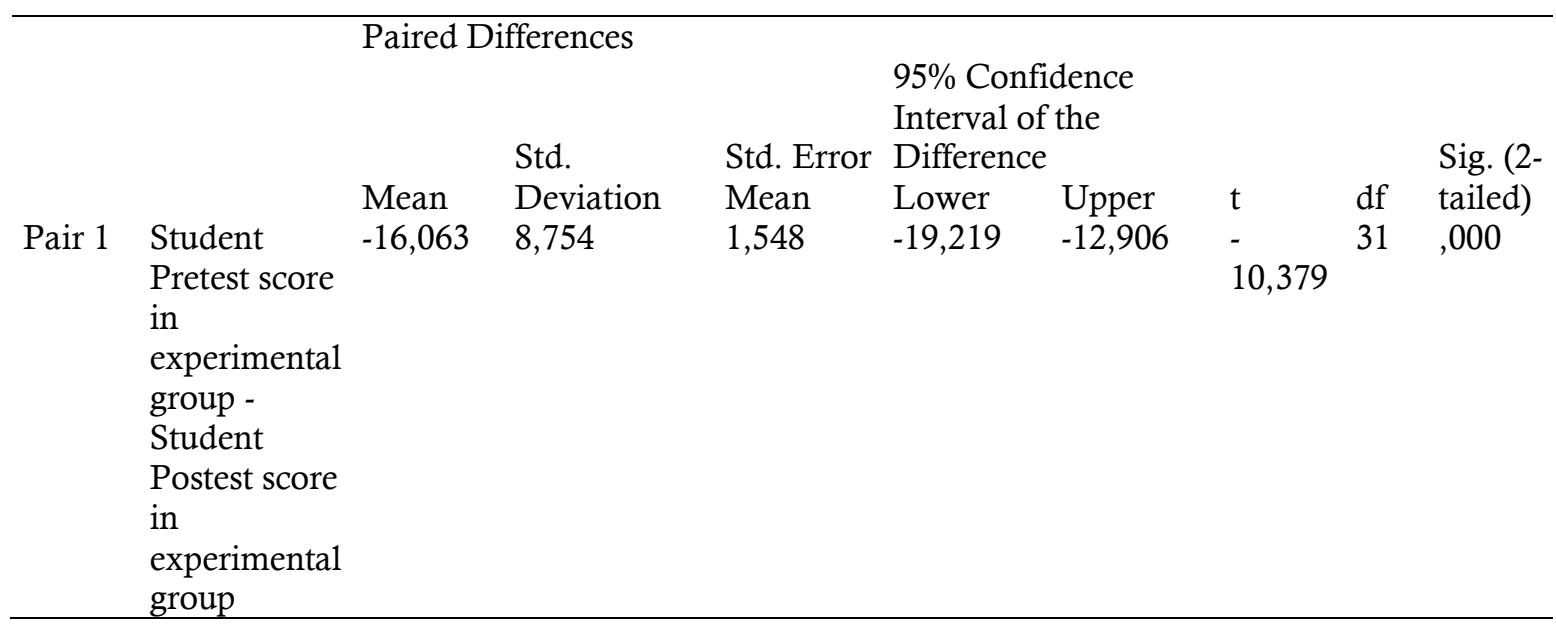

Table 5 shows that calculation of t-test for research problems number 1 . It was found that p-output was 0.000 . When the p-output was lower than $\alpha 0,05$ it is significant. It meant that there was sigificant difference in writing ability between the students who have high motivation and those who have low motivation taught by using collaborative writing strategy with google docs.

Table $6<$ Paired Sample T Test Hypothesis 2>

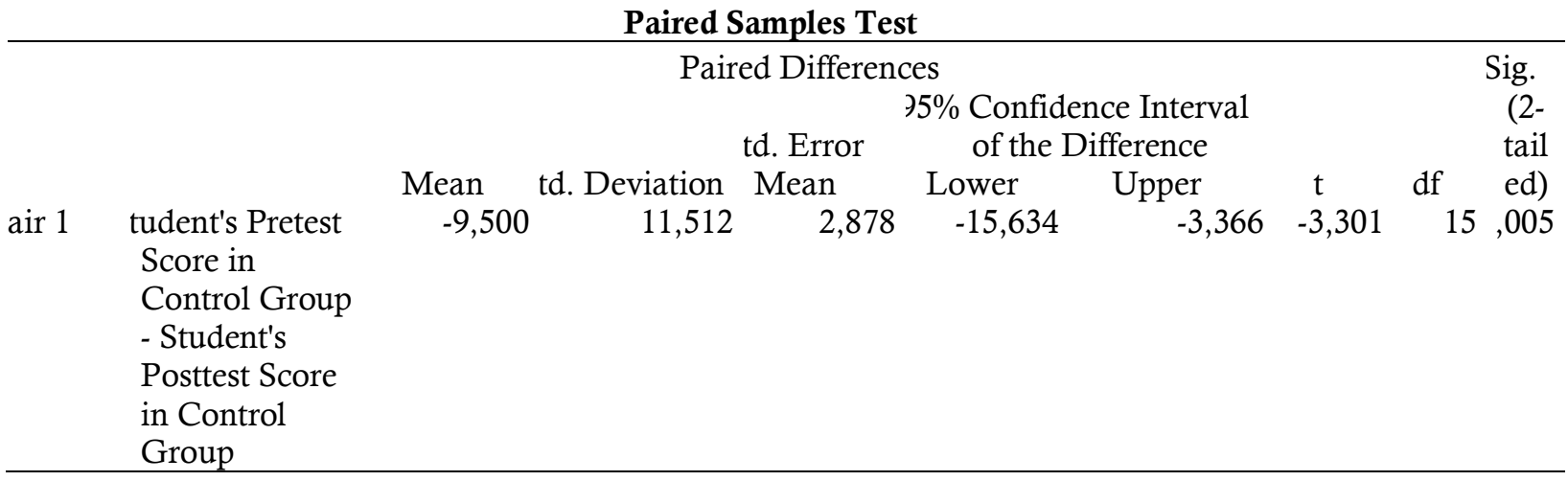

Table 6 shows that calculation of t-test for research problems number 2. It was found that p-output was 0.005 . When the p-output was lower than $\alpha 0,05$ it is significant. It meant that there was significant 
difference in writing ability between the students who have high motivation and those who have low motivation taught by using conventional writing strategy.

Table 7<Independent Sample T test Hypothesis 3> Independent Samples Test

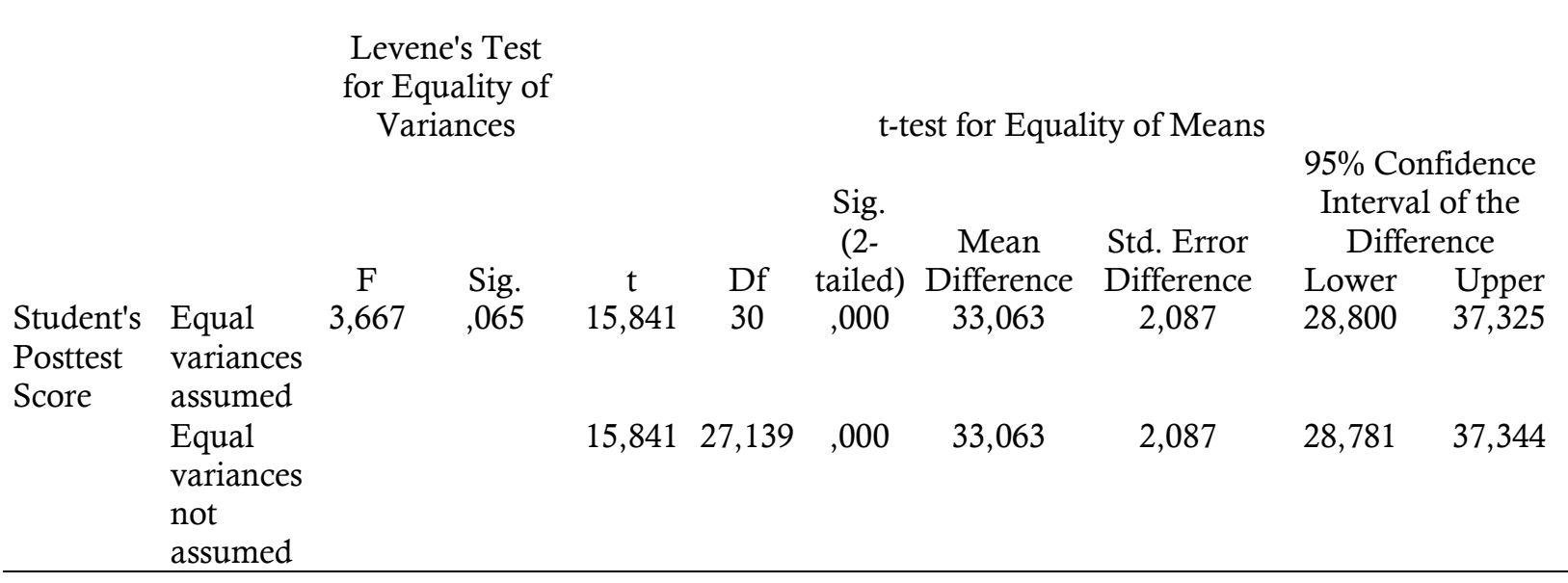

Table 7 shows that calculation of t-test for research problems number 3 . It was found that p-output was 0.000 . When the p-output was lower than $\alpha 0,05$ it is significant. It meant that there was significant difference in writing ability between the students who have high motivation and those who have low motivation taught by using collaborative writing startegy with google docs and conventional writing strategy.

Then Based on Tests of Between-Subjects Effects, it was found that the p-output of motivation was 0.001 . This value was lower than 0.05 , it was significant different. It can be interpreted that There was significant interaction effect of collaborative writing strategy with google docs and motivation towards eight grade students' writing ability on descriptive text.

Table 8 <Two Way Anova Hypothesis 4>

\section{Tests of Between-Subjects Effects}

Dependent Variable: Score

\begin{tabular}{|c|c|c|c|c|c|}
\hline $\begin{array}{l}\text { Source } \\
\text { Corrected Model }\end{array}$ & $\begin{array}{l}\text { Type III Sum of } \\
\text { Squares } \\
14957,125^{\mathrm{a}}\end{array}$ & $\mathrm{df}_{3}$ & $\begin{array}{r}\text { Mean Square } \\
4985,708\end{array}$ & $\begin{array}{l}\mathrm{F} \\
182,085\end{array}$ & $\begin{array}{l}\text { Sig. } \\
, 000\end{array}$ \\
\hline Intercept & 320356,000 & 1 & 320356,000 & 11699,831 & 000 \\
\hline Method & 13053,063 & 1 & 13053,063 & 476,715 & ,000 \\
\hline Motivation & 1580,063 & 1 & 1580,063 & 57,706 & 000 \\
\hline Method * Motivation & 324,000 & 1 & 324,000 & 11,833 & 001 \\
\hline Error & 1642,875 & 60 & 27,381 & & \\
\hline Total & 336956,000 & 64 & & & \\
\hline Corrected Total & 16600,000 & 63 & & & \\
\hline
\end{tabular}

a. R Squared $=, 901$ (Adjusted R Squared $=, 896$ )

\section{Discussion}

Based on the finding of the study, there were some interpretation: First,there was any significant difference in writing ability between the students who have high motivation and those who have low motivation taught by using collaborative writing strategy with google docs. The significance value of both the high and low motivation with collaborative writing strategy with google docs was 0.000 which is lower than $a=0.05$. it means that there was any significant difference in average of writing ability between the students with high and those with low motivation after being taught through collaborative writing strategy with google docs at SMPN 12 palembang. 
Second, there was any significant difference in writing ability between the students who have high motivation and those who have low motivation taught by using conventional writing strategy. The significance value of both the high and low motivation by using conventional teaching technique was 0.000 which is lower than $\mathrm{a}=0.05$. it conduded that there was any significant difference in writing ability between eight grade students' with high motivation and those with low motivation who taught by using conventional teaching technique.

Third, there was any significant difference in writing ability between the students who have high motivation and those who have low motivation taught by using collaborative writing startegy with google docs and conventional writing strategy. The significance value of both the experimental and control group in high motivation was 0.000 which is lower than $=0.05$. it means that $(\mathrm{Ha})$ was accepted and $(\mathrm{Ho})$ was rejected. In other words, there was any significant difference in writing ability between eigth grade students' with high motivation who were taught by using collaborative writing strategy with google docs and those who were taught by using conventional teaching technique.

Fourth, there was any significant interaction effect of collaborative writing strategy with google docs and motivation towards eight grade students' writing ability on descriptive text. Based on the statistical result of interaction effect (influence) of collaborative with google docs and students' leaming motivation toward writing ability. It showed that sig p-value was 0,043 was lower than $a=0.05$. So, there was a significant interaction. This finding indicated that there was interaction between collaborative writing strategy with google docs and motivation toward writing ability. It means that the collaborative writing strategy with google docs was effective for the students who have high and Low motivation.

Based on the previous related study in the previour chapter. The implementing of collaborative writing strategy with google docs in learning process can increased writing ability. After was given treatment through collaborative learning method, it was found that the mean score of high motivation in the posttest was was 76.60 which is higher than the mean score of low motivation was 66.33. The gain scores in pretest-posttest in high motivation was 11.47 while the pretest posttest results in low motivation was 16.13 . in other words, there was any significant increase in high motivation which compared in low motivation. it could be concluded that the strategy which applied to develop students writing ability was effective in both group of students' high motivation and students' low motivation . in ddition students with high motivation preferred most by the collaborative learning method.

[8] Collaborative learning in writing focuses on the process of problem solving and thinking together. Collaborative learning gives opportunities to students who skilled in writing (that sometimes are not detected) to share the knowledge to others. In addition, [8] Believes that collaborative learning improves the students' communicative ability and automatically improves their positive social attitude in learning and their life. In writing, collaborative learning conducted by the process of writing a work, reading it, reviewing,giving over and over correction, discussing, question and answering, and giving comments

[6] Google Docs is a productive tool where learning activities can be designed differently and creatively. Google docs is one of media that can be used to increase student motivation in writing abilty. The students with low motivation can be shown the questionnaire in number 9-15 told us about students' low motivation. The motivation of students will improve if there are good equipment and creative media in the teaching learning process. And also need strategies in the leaming process, so that the teachers should be active and creative using strategies or creative media to create a comfortable situation in the classroom like using google doc. The students with high motivation can be shown in number 1-8, and 16-20 related to the students' high motivation. They were always active in the learning process both inside and outside the classroom such as they always act on English lesson, always ask when the teacher explain the materials, they were happy to answer questions using the English language during the learning process and always practice English outside the classroom.

In this research, the writer found that collaborative learning method was successful in improving the motivation of the students in writing text and improving the writing ability of the students. The students had more opportunities to share their ideas with their friends and to help each other make a good writing text. This activity had a big influence to the students motivation in writing. The students were more enthusiastic and interested in writing by using google docs and the features. Working together helped them in understanding the materials. They didn't feel bored anymore when they have assignment to write a text.

For Google Docs, students know that their teacher can check who is working less or more during the lesson process. Thus, students in Google Docs groups are more serious about collaborating and are willing to take part in group conventions and practices. This can affect the improvement of the writing skills of both groups. 
The research finding was also supported by students' motivation towards collaboration in writing assignments outside the classroom using Google Docs. This may be because Google Docs makes collaboration easier. It can be accessed by the general public, regardless of location, as long as the Internet is available [9]

The findings show how responsible students are for their written assignments. Students learn how to work together in teams. In this study, Google Docs was seen as the kind of user friendly they used to complete tasks. This increases student motivation and supports what Swain \& Lapkin in Suwantarathip,O.,\& Wichadee,S. (2014) stated that students who work in collaborative groups appear satisfied with their class, and their learning motivation increases.

In short, it can be concluded that collaborative writing strategy with google docs and motivation were two factors to determine writing ability. There was significant interaction effect of collaborative writing strategy with google docs to students who have high motivation toward students' writing ability on descriptive text at SMPN 12 Palembang.

\section{Conclusions}

Based on findings and discussions the conclusions were presented as follows:(1)There was significant difference in writing ability between the students who have high motivation and those who have low motivation taught by using collaborative writing strategy with google docs at SMPN 12 Palembang.(2)There was significant difference in writing ability between the students who have high motivation and those who have low motivation taught by using conventional writing strategy at SMPN 12 Palembang. (3)There was significant difference in writing ability between the students who have high motivation and those who have low motivation taught by using collaborative writing startegy with google docs and conventional writing strategy at SMPN 12 Palembang. (4)There was significant interaction effect of collaborative writing strategy with google docs and motivation towards eight grade students' writing ability on descriptive text at SMPN 12 Palembang.

\section{References}

Brown, H. Douglas. 2004. Language Assessment: Principles and Classroom Practices. New York: Longman. Zhou, W., Simpson, E., \& Domizi, D. P. 2012. Google Docs in an Out-of-Class Collaborative Writing Activity. International Journal of Teaching and Learning in Higher Education, 24(3), 359-375.

Haring-Smith, T. 1994. Writing together: Collaborative learning in thewriting classroom. New York, NY: Harper Collins CollegePublishers

Oxford. 1997. Oxford Advanced Learner's Dictionary. Press Parenting Resource. 2019. Retrieved from ELT Learning: https://www.etllearning.com/resources/5- reasons-why-reading-habits-are-important

Thompson, J. (2007). Is Education 1.0 ready for Web 2.0 students? Innovate:Journal of Online Education, 3(4), 5

Chinnery, G. M. 2008. ON THE NET You've Got some GALL: Google-

Assisted Language Learning. Language, Learning and Technology, 12(1),3-11

Simaibang, Baginda. 2017. English Language Teaching In a Foreign Situation (Second Edition): Palembang: CV. Citra Books Indonesia.

Nelson, Stephanie. 2000. Teaching Collaborative Writing and Peer Review Techniques to Engineering and Technology Undergraduates.Frontier in Education Conference,2000. FIE 2000. 30th Annual. Retrieved from: ieeexplore.ieee.org

Suwantarathip, O., \& Wichadee, S. 2014. The Effects of Collaborative Writing Activity Using Google Docs on Students' Writing Abilities. Turkish Online Journal of Educational Technology-TOJET, 13(2), 148-156. 